\title{
man \\ Oral Administration of Nicotinamide Mononucleotide Increases Nicotinamide Adenine Dinucleotide Level in an Animal Brain
}

\author{
Chidambaram Ramanathan ${ }^{1, *(\mathbb{D})}$, Thomas Lackie ${ }^{1}$, Drake H. Williams ${ }^{2}$, Paul S. Simone ${ }^{2}$, Yufeng Zhang ${ }^{1}$ \\ and Richard J. Bloomer ${ }^{1}$
}

check for

updates

Citation: Ramanathan, C.; Lackie, T.; Williams, D.H.; Simone, P.S.; Zhang, Y.; Bloomer, R.J. Oral Administration of Nicotinamide Mononucleotide Increases Nicotinamide Adenine Dinucleotide Level in an Animal Brain. Nutrients 2022, 14, 300 . https://doi.org/10.3390/ nu14020300

Academic Editor: Donald K. Ingram

Received: 17 December 2021

Accepted: 9 January 2022

Published: 12 January 2022

Publisher's Note: MDPI stays neutral with regard to jurisdictional claims in published maps and institutional affiliations.

Copyright: (C) 2022 by the authors. Licensee MDPI, Basel, Switzerland. This article is an open access article distributed under the terms and conditions of the Creative Commons Attribution (CC BY) license (https:// creativecommons.org/licenses/by/ $4.0 /)$.
1 College of Health Sciences, University of Memphis, Memphis, TN 38152, USA; talackie@memphis.edu (T.L.); yzhang24@memphis.edu (Y.Z.); rbloomer@memphis.edu (R.J.B.)

2 Department of Chemistry, University of Memphis, Memphis, TN 38152, USA; dhwllms3@memphis.edu (D.H.W.); psimone@memphis.edu (P.S.S.)

* Correspondence: rchdmbrm@memphis.edu

\begin{abstract}
As a redox-sensitive coenzyme, nicotinamide adenine dinucleotide $\left(\mathrm{NAD}^{+}\right)$plays a central role in cellular energy metabolism and homeostasis. Low $\mathrm{NAD}^{+}$levels are linked to multiple disease states, including age-related diseases, such as metabolic and neurodegenerative diseases. Consequently, restoring/increasing $\mathrm{NAD}^{+}$levels in vivo has emerged as an important intervention targeting age-related neurodegenerative diseases. One of the widely studied approaches to increase $\mathrm{NAD}^{+}$levels in vivo is accomplished by using $\mathrm{NAD}^{+}$precursors, such as nicotinamide mononucleotide (NMN). Oral administration of NMN has been shown to successfully increase $\mathrm{NAD}^{+}$levels in a variety of tissues; however, it remains unclear whether NMN can cross the blood-brain barrier to increase brain $\mathrm{NAD}^{+}$levels. This study evaluated the effects of oral NMN administration on $\mathrm{NAD}^{+}$ levels in C57/B6J mice brain tissues. Our results demonstrate that oral gavage of $400 \mathrm{mg} / \mathrm{kg} \mathrm{NMN}$ successfully increases brain $\mathrm{NAD}^{+}$levels in mice after $45 \mathrm{~min}$. These findings provide evidence that NMN may be used as an intervention to increase $\mathrm{NAD}^{+}$levels in the brain.
\end{abstract}

Keywords: $\mathrm{NAD}^{+}$; NMN; brain; oral gavage; mice

\section{Introduction}

The oxidized form of nicotinamide adenine dinucleotide $\left(\mathrm{NAD}^{+}\right)$is an electron carrier and signaling molecule found virtually in every cell in our body and is involved in a broad spectrum of biological processes [1,2]. $\mathrm{NAD}^{+}$is a coenzyme for redox reactions, functioning as a critical regulator to maintain physiological processes [3]. Changes in $\mathrm{NAD}^{+}$levels are reported during aging and age-related diseases, such as diabetes, cancer, neurodegeneration, and cardiovascular diseases [4]. Preclinical studies suggest that NAD metabolism and/or NAD ${ }^{+} / \mathrm{NADH}$ redox balance are potential therapeutic targets $[5,6]$.

Numerous approaches have been employed to manipulate $\mathrm{NAD}^{+}$levels in cells and in vivo [7]. $\mathrm{NAD}^{+}$levels can be increased by activating enzymes that stimulate the synthesis of $\mathrm{NAD}^{+}$[8]. It can also be done by inhibiting an enzyme (CD38) that degrades $\mathrm{NAD}^{+}[9,10]$ and also by supplementing with NAD precursors, including nicotinamide riboside (NR) and nicotinamide mononucleotide (NMN) [6]. Although nicotinamide/nicotinic acid and nicotinamide ribose (NR) can both be used as precursors for synthesizing $\mathrm{NAD}^{+}, \mathrm{NMN}$ is a predominant precursor in mammals [11]. NMN is a bioactive nucleotide containing a nicotinamide, ribose, and a phosphate group [12]. Naturally, the NMN is found in small amounts in fruits and vegetables, such as avocados, broccoli, cabbage, edamame, and cucumbers. Taken orally, NMN can be rapidly absorbed and converted to $\mathrm{NAD}^{+}$by the enzyme nicotinamide/nicotinic acid mononucleotide adenylyltransferase (NMNAT) [6] In several studies, supplementation with NMN suppressed age-related adipose tissue 
inflammation, enhanced insulin secretion and insulin action, improved mitochondrial function, and improved neuronal function in the brain $[6,13,14]$.

Studies from rodents have demonstrated that physiological NMN administration effectively enhances $\mathrm{NAD}^{+}$biosynthesis in multiple peripheral tissues, including the pancreas [11], liver [11,15,16], adipose tissue [17], heart [18,19], skeletal muscle [10], kidney [20], eyes [21], and blood vessels [22]. Even though it is not known how NMN can cross the blood-brain barrier (BBB) [6], intraperitoneal NMN administration rapidly increases $\mathrm{NAD}^{+}$ levels in the hippocampus and hypothalamus brain regions [13,23], indicating the NMN could pass through the $\mathrm{BBB}$ and act as a substrate for $\mathrm{NAD}^{+}$biosynthesis in the brain regions. However, direct evidence of manipulation of $\mathrm{NAD}^{+}$levels in the brain through oral NMN administration is still lacking. Consequently, in the present study, we administered NMN through oral gavage and tested whether it changed $\mathrm{NAD}^{+}$levels in the brain tissue in mice. We hypothesized that oral administration of NMN would rapidly increase $\mathrm{NAD}^{+}$levels in the brain. This study would help us to understand the effects of oral NMN administration on brain $\mathrm{NAD}^{+}$levels, which would allow us to evaluate the possibility of using oral $\mathrm{NMN}$ administration to increase $\mathrm{NAD}^{+}$levels in vivo.

\section{Materials and Methods}

\section{Animals}

This study was conducted under the University of Memphis IACUC permit (\#0872). Twelve, four-week-old male C57BL/6J mice were purchased from the Jackson Laboratory. Our sole use of healthy, male mice should be viewed as a limitation of this work. Mice were housed in the animal facility with $12 \mathrm{~h}$ light $/ 12 \mathrm{~h}$ dark cycles with ad libitum food and water for a one week acclimation period. Mice were then separated into a control group and the NMN group. NMN administration was accomplished by using CalerieHealth ${ }^{\mathrm{TM}}$ SOD+, a $100 \% \beta-N M N$ isoform supplement (CalerieHealth ${ }^{\mathrm{TM}}$, Anaheim, CA, USA). Tablets of CalerieHealth ${ }^{\mathrm{TM}}$ SOD+NMN were dissolved in PBS at a concentration of $720 \mathrm{mg} / \mathrm{mL}$ of NMN. NMN group mice $(n=6)$ received NMN $(400 \mathrm{mg} / \mathrm{kg})$ through oral gavage. For example, for an average 4-week-old mouse weighed at $16 \mathrm{~g}$, $88.9 \mu \mathrm{L}$ of CalerieHealth ${ }^{\mathrm{TM}}$ $\mathrm{SOD}+\mathrm{NMN}$ solution was administrated through oral gavage. The control group mice $(n=6)$ received the same volume of PBS compared to their NMN group counterparts. After $45 \mathrm{~min}$, mice were euthanized by $\mathrm{CO}_{2}$, and the whole brain was quickly dissected and snap-frozen in liquid nitrogen. Skeletal muscles (leg muscles) were dissected and snap-frozen in liquid nitrogen. Tissues were stored at $-80^{\circ} \mathrm{C}$ for future analysis of $\mathrm{NAD}^{+}$(in brain, as described below) and SOD (skeletal muscle, via Western blot). This latter analysis was not a primary purpose of the study, and no significant differences were detected due to the small sample size; hence, data are not shown.

$\mathrm{NAD}^{+}$in brain tissues was extracted through acid extraction according to Yoshino and Imai [24]. Briefly, pre-chilled $10 \% \mathrm{HClO}_{4}$ solution was added in the left side of each brain at a 1:10 ratio (tissue weight: $\mathrm{HClO}_{4}$ volume) and homogenized using a Polytron Homogenizer on ice. Then, the homogenates were centrifuged at maximal speed $(\sim 15,000 \times g)$ for $5 \mathrm{~min}$ at $4{ }^{\circ} \mathrm{C}$. Supernatants were transferred to new tubes, and one-third volume of $3 \mathrm{M} \mathrm{K}_{2} \mathrm{CO}_{3}$ was added and mixed well. Samples were centrifuged again at maximal speed $(\sim 15,000 \times g)$ for $5 \mathrm{~min}$ at $4{ }^{\circ} \mathrm{C}$. Supernatants were transferred to new tubes and frozen at $-80^{\circ} \mathrm{C}$ until HPLC-Mass Spectrometry measurements.

$\mathrm{NAD}^{+}$levels in samples were measured using HPLC-Mass Spectrometry according to Mills, et al. [15]. For the separation and analysis, a Waters AQUITY UPLC with a Waters Quattro Micro Triple-Quadrupole Mass Spectrometer was operated in binary gradient mode. The binary gradient employed was comprised of $5.0 \mathrm{mM}$ ammonium formate in an aqueous solution for solvent $\mathrm{A}$ and methanol for solvent $\mathrm{B}$. The initial conditions were $100 \%$ solvent $\mathrm{A}$ and held for $1 \mathrm{~min}$. From $1 \mathrm{~min}$ to $3 \mathrm{~min}$, the concentration of solvent A decreased to $30 \%$ of initial with the remaining $70 \%$ as solvent B. This was held for $1 \mathrm{~min}$. From $4 \mathrm{~min}$ to $5 \mathrm{~min}$, solvent composition returned to initial conditions and held until the end of the run. The mass spectrometer was operated in ESI positive mode 
with multiple reaction monitoring (MRM) using the $664 \mathrm{~m} / \mathrm{z}>428 \mathrm{~m} / \mathrm{z}$ transition for $\mathrm{NAD}^{+}$. The acquisition window for $\mathrm{NAD}^{+}$was 2.0-3.5 min. The operating voltages were as follows: the capillary voltage was $0.8 \mathrm{kV}$, the cone voltage was $30 \mathrm{~V}$, and the collision cell voltage was $30 \mathrm{~V}$. A stock standard solution of NAD+ was prepared at a concentration of $0.2 \mathrm{mg} / \mathrm{mL}$ and serially diluted to produce seven calibration standards in the range of 100 to $10,000 \mu \mathrm{g} / \mathrm{L}$. A check standard was analyzed seven consecutive times at $500 \mu \mathrm{g} / \mathrm{L}$ to determine the method detection limit [25], accuracy and precision [26]. The method detection limit was determined by multiplying the standard deviation of the reported check standard conversation by a Student's t-value at the $98 \%$ confidence level for $\mathrm{n}-1$ degrees of freedom. Accuracy was estimated as mean \% recovery of the reported check standard concentration. Precision was estimated as \% relative standard deviation of the reported check standard concentration. The method detection limit for $\mathrm{NAD}^{+}$was $77.4 \mu \mathrm{g} / \mathrm{L}$, the accuracy was estimated as $117 \%$, and the precision was estimated as $4.2 \%$ RSD.

Results are expressed as mean \pm SEM, and statistical differences were calculated using a paired $t$-test with IBM SPSS.

\section{Results}

For this study, we have documented an increase of $\mathrm{NAD}^{+}$levels in brain tissues following oral administration of NMN (Figure 1). The dosage of NMN was $400 \mathrm{mg} / \mathrm{kg}$, within the range of dosages (300-500 mg/kg) used in previous studies [6]. The mice treated with NMN significantly increased the $\mathrm{NAD}^{+}$levels more than $40 \%$ compared to their control counterparts $\left(t_{5}=2.878, p=0.0347\right.$; Figure 1$)$. The results from the present study demonstrate that NMN can increase brain $\mathrm{NAD}^{+}$levels rapidly, likely via passing through the blood-brain barrier (Note: since we did not measure blood NMN levels, we made the assumption that oral administration first led to increased blood NMN and then subsequently yielded the increase in brain $\mathrm{NAD}^{+}$.).

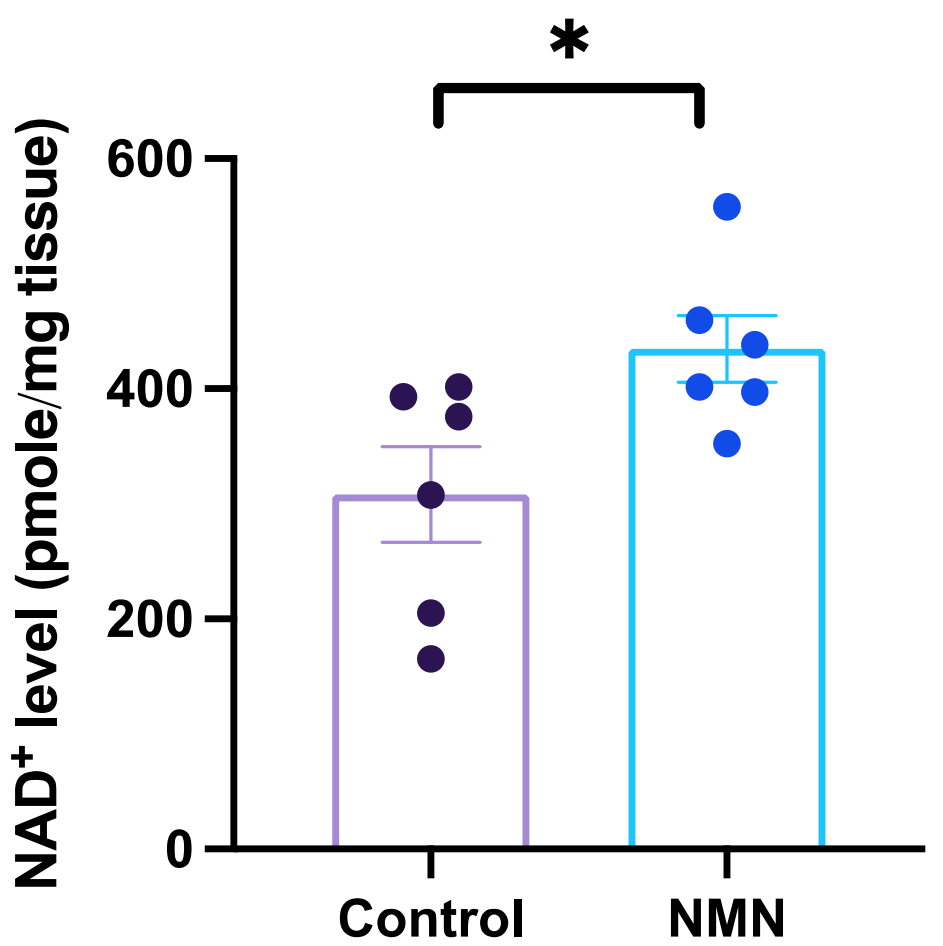

Figure 1. Oral gavage administration of nicotinamide mononucleotide (NMN) increases nicotinamide adenine dinucleotide $\left(\mathrm{NAD}^{+)}\right.$in brain tissue of mice. Data are expressed as mean $\pm \mathrm{SEM}$. The histogram depicts the $\mathrm{NAD}^{+}$level in the brain tissues of NMN (400 mg/kg) and PBS (control) administrated mice $45 \mathrm{~min}$ after oral gavage. ${ }^{*}$ indicates $p=0.0347$. 


\section{Discussion}

Considering our data, similar results have been observed in mice that received NMN (300 mg/kg) and brain tissues collected $60 \mathrm{~min}$ after oral gavage [15]. Similar to this study, Mills et al. [15] had observed a slight increase in NAD levels, though not significantly, in the cortex of mice compared with their controls. These results indicate that the higher dosage $(400 \mathrm{mg} / \mathrm{kg}$ ) employed in the present study would be more beneficial to manipulate brain $\mathrm{NAD}^{+}$levels. Moreover, the dosages and treatment time might also be different depending on the tissues of interest and administration methods. For example, oral administration of NMN $(300 \mathrm{mg} / \mathrm{kg})$ in mice has been shown to increase NAD ${ }^{+}$levels in plasma as quickly as $2.5 \mathrm{~min}$ and return back to the original levels at $15 \mathrm{~min}$. However, liver and skeletal muscle changes were not observed until $15 \mathrm{~min}$ [15]. On the other hand, administrating NMN $(500 \mathrm{mg} / \mathrm{kg})$ intraperitoneally increased $\mathrm{NAD}^{+}$levels in the liver, pancreas, and white adipose tissue in $15 \mathrm{~min}$ [11]. Hence, dosages and treatment time of NMN targeting an increase in $\mathrm{NAD}^{+}$levels should be optimized for administration methods and tissues of interest. As cellular $\mathrm{NAD}^{+}$homeostasis is regulated by the balance between $\mathrm{NAD}^{+}$consuming enzymes and the $\mathrm{NAD}^{+}$synthesizing enzymes, NMN effects are only short-lived $[3,27]$. It is well known that NMN is soluble in water and saline and is taken up more efficiently through the plasma membrane. The cells immediately convert the NMN into $\mathrm{NAD}^{+}$. The $\mathrm{NAD}^{+}$consuming enzymes, such as sirtuins, poly-ADPribose polymerases (PARPs), and CD38/157 ectoenzymes, used the excess $\mathrm{NAD}^{+}$for many biological processes and reduced the extra level of $\mathrm{NAD}^{+}$to the average physiological level $[28,29]$. At the same time, the biosynthetic pathway also plays a primary role in maintaining the physiological level of $\mathrm{NAD}^{+}$. Among three $\mathrm{NAD}^{+}$biosynthetic pathways, the salvage pathway is the most predominant, and it is controlled by an endogenous circadian clock. The cellular circadian clock senses the level of $\mathrm{NAD}^{+}$and activates the NAMPT, a rate-limiting enzyme for $\mathrm{NAD}^{+}$synthesis, and controls the salvage pathway by generating a homeostatic level of the $\mathrm{NAD}^{+}$at the cellular level [30,31].

The result suggests that NMN may offer a broad application and therapeutical potential. A growing body of evidence shows that NMN has beneficial effects on various neurodegenerative mice models, such as Alzheimer's disease, Parkinson's disease, and cognitive deficit models (Table 1). Age-related decline of cellular $\mathrm{NAD}^{+}$levels contributes to various age-related diseases, especially neurodegenerative diseases, including Alzheimer's, Parkinson's, and Retinal degenerative diseases [1]. NAD ${ }^{+}$sirtuin axis plays an important role in preventing neuronal cell death, which is commonly observed in these neurodegenerative disorders. In mice, cortex and hippocampal NAD levels decrease in the early age of Alzheimer's and Parkinson's disease [32,33]. In Alzheimer's disease, the decrease of NAD ${ }^{+}$ levels has been shown to be associated with decreased activity of nicotinamide phosphoribosyltransferase (NAMPT) [34]. NAMPT is a vital enzyme in cells that convert nicotinamide to $\mathrm{NMN}$, where NMN can be further converted to $\mathrm{NAD}^{+}$by nicotinamide/nicotinic acid mononucleotide adenylyltransferase [35].

Consequently, NMN treatment would bypass the decreased NAMPT activity in Alzheimer's disease patients, which can be used as a potential treatment. Studies with Alzheimer's disease mouse models have documented that NMN supplementation reduces neural death and enhances cognitive function $[14,38,40]$. Similarly, in retinal degenerative diseases, retinal degeneration and blindness were often caused by malfunction of retina-specific NAMPT [21]. In this study, the administration of NMN could be used to restore retinal function and rescue vision. Moreover, NMN had also shown significant beneficial effects by attenuating neuronal cell apoptosis and improving energy metabolism in a cellular model of Parkinson's disease. Thus, $\mathrm{NAD}^{+}$metabolism is recognized as an attractive target for nutritional intervention against various neuronal disorders. $\mathrm{NAD}^{+}$ precursors, such as NMN, could be used as a potent supplement against various age-related neurodegenerative diseases. 
Table 1. Effects of NMN administration and level of $\mathrm{NAD}^{+}$in mice brain

\begin{tabular}{|c|c|c|c|c|}
\hline Mice Model & Intervention & $\begin{array}{c}\text { Percentage of NAD } \\
\text { Increased in Brain Tissues }\end{array}$ & Effects & Reference \\
\hline $\begin{array}{l}\text { Triple transgenic } \\
\text { Alzheimer's disease } \\
\text { model mice }\end{array}$ & $\begin{array}{l}\text { NMM (40 } \mu \mathrm{g} / \mathrm{g} / \text { day) for } \\
\text { eight months }\end{array}$ & Unspecified & $\begin{array}{c}\text { Reduced beta } \\
\text { amyloid }(\mathrm{A} \beta) \text {, } \\
\text { improved brain } \\
\text { bioenergetics and } \\
\text { preserved } \\
\text { mitochondrial } \\
\text { functionality. }\end{array}$ & Liu, et al. [36] \\
\hline C57BL/6N & $\begin{array}{c}\text { NMN (i.p. } \\
500 \text { mg/kg/day) single } \\
\text { dose. }\end{array}$ & $\begin{array}{l}\text { Hippocampal tissue; } 34-39 \% \\
\text { within } 15 \text { min. }\end{array}$ & Unspecified & Stein and Imai [23] \\
\hline C57BL/6N & $\begin{array}{l}\text { NMN (drinking water; } 100 \\
\text { or } 300 \mathrm{mg} / \mathrm{kg} / \text { day) for } \\
12 \text { months }\end{array}$ & Unspecified & $\begin{array}{c}\text { Maintain neural } \\
\text { stem/progenitor cells } \\
\text { proliferation and } \\
\text { self-renewal with age. }\end{array}$ & Stein and Imai [23] \\
\hline $\begin{array}{l}\text { PC12 cells (Parkinson's } \\
\text { disease cellular model) }\end{array}$ & $\begin{array}{l}\text { NMN ( } 0.1 \mathrm{mM} \text { to } 1 \mathrm{mM}) . \\
\text { The treated cells were } \\
\text { incubated for } 24 \mathrm{~h} .\end{array}$ & - & $\begin{array}{l}\text { Reduced the } \\
\text { rotenone-induced } \\
\text { apoptosis and restored } \\
\text { intracellular NAD } \text { N }^{+} \text {level } \\
\text { and ATP. }\end{array}$ & Lu, et al. [37] \\
\hline $\begin{array}{c}\text { C57BL/6N } \\
\text { Adipose tissue-specific } \\
\text { Nampt KO (ANKO) }\end{array}$ & $\begin{array}{l}\text { NMN (i.p. } 500 \mathrm{mg} / \mathrm{kg} \\
\text { / day) single dose }\end{array}$ & $\begin{array}{c}\text { Individual hypothalamic } \\
\text { nuclei (Arc, VMH, DMH, and } \\
\text { LH); } 1.5 \text { to } 3.5 \text {-fold increase } 1 \mathrm{~h} \\
\text { after NMN administration. }\end{array}$ & $\begin{array}{l}\text { Improved physical activity } \\
\text { of the mice compared with } \\
\text { control in the first half of } \\
\text { the } 12 \text { h dark time. }\end{array}$ & Yoon, et al. [13] \\
\hline $\begin{array}{l}\text { APPswe/PS1dE9 (AD-Tg) } \\
\text { mice }\end{array}$ & $\begin{array}{c}\text { NMN (s.c. } \\
100 \mathrm{mg} / \mathrm{kg} / \text { day) for every } \\
\text { other day for } 28 \text { days. }\end{array}$ & $\begin{array}{l}\text { Forebrain tissue was examined } \\
\text { after } 24 \mathrm{~h} \text { NMN injection; the } \\
\% \text { of increased NAD }{ }^{+} \text {level } \\
\text { was unspecified. }\end{array}$ & $\begin{array}{l}\text { Increased mitochondrial } \\
\text { respiratory function and } \\
\text { decreased amyloid } \\
\text { precursor protein (APP). }\end{array}$ & Long, et al. [38] \\
\hline C57BL/6N & $\begin{array}{l}\text { MNM (oral gavage; } \\
300 \text { mg/kg) single dose. }\end{array}$ & $\begin{array}{l}\text { Cortex; } \\
\sim 10 \% \text { increased within } 60 \mathrm{~min}\end{array}$ & Unspecified & Mills, et al. [15] \\
\hline C57BL/6N & $\begin{array}{l}\text { NMN (drinking water; } 100 \\
\text { and } 300 \mathrm{mg} / \mathrm{kg} / \text { day) for } \\
12 \mathrm{months} .\end{array}$ & Unspecified & $\begin{array}{l}\text { Improved the rod cells } \\
\text { functions in aged mice. }\end{array}$ & Mills, et al. [15] \\
\hline C57BL/ 6 & $\begin{array}{c}\text { NMN (i.p. } \\
62.5 \text { mg/kg/day) Single } \\
\text { dose. }\end{array}$ & $\begin{array}{l}\text { Hippocampal tissue was } \\
\text { examined; the \% of increased } \\
\mathrm{NAD}^{+} \text {level was unspecified. }\end{array}$ & $\begin{array}{l}\text { Ameliorated hippocampal } \\
\text { CA1 injury. }\end{array}$ & Park, et al. [39] \\
\hline $\begin{array}{l}\text { Wister rat (Alzheimer's } \\
\text { diease model) }\end{array}$ & $\begin{array}{l}\text { NMN (i.p. } \\
500 \text { mg/kg/day) for } \\
10 \text { days. }\end{array}$ & $\begin{array}{l}\text { Hippocampal tissue was } \\
\text { examined after the treatment; } \\
\text { the } \% \text { of increased NAD }{ }^{+} \text {level } \\
\text { was unspecified. }\end{array}$ & $\begin{array}{l}\text { Restored the level of } \\
\text { NAD }^{+} \text {and ATP; } \\
\text { eliminated ROS } \\
\text { accumulation in } \\
\text { hippocampal tissue. }\end{array}$ & Wang, et al. [40] \\
\hline $\begin{array}{l}\text { APPswe/PS1dE9 double } \\
\text { transgenic (AD-Tg) mice }\end{array}$ & $\begin{array}{c}\text { NMN (s.c. } \\
100 \mathrm{mg} / \mathrm{kg} / \text { day) every } \\
\text { other day for } 28 \text { days }\end{array}$ & Unspecified & $\begin{array}{c}\text { Decreased } \beta \text {-amyloid } \\
\text { production and increased } \\
\text { cognitive function. }\end{array}$ & Yao, et al. [14] \\
\hline $\begin{array}{c}\text { C57BL } / 6 \\
\text { (CA1-specific Nampt } \\
\text { knockdown mice) }\end{array}$ & $\begin{array}{l}\text { NMN (oral gavage. } \\
300 \mathrm{mg} / \mathrm{kg} \text { / day) for three } \\
\text { weeks. }\end{array}$ & $\begin{array}{l}\text { Hippocampal tissue was } \\
\text { examined; the \% of increased } \\
\text { NAD }^{+} \text {level was unspecified. }\end{array}$ & $\begin{array}{l}\text { Increased level of } \mathrm{NAD}^{+} \\
\text {and improved cognitive } \\
\text { function in old } \\
\text { 20-month-old mice. }\end{array}$ & Johnson, et al. [41] \\
\hline C57BL/ 6 & $\begin{array}{c}\text { NMN (i.p. } \\
62.5 \mathrm{mg} / \mathrm{kg} / \text { day) single } \\
\text { dose. }\end{array}$ & $\begin{array}{l}\text { Hippocampal tissue was } \\
\text { examined after } 24 \mathrm{~h} \text {; the \% of } \\
\text { increased NAD }{ }^{+} \text {level was } \\
\text { unspecified. }\end{array}$ & $\begin{array}{l}\text { Reduced mitochondrial } \\
\text { fission and ROS in the } \\
\text { hippocampus. }\end{array}$ & Klimova, et al. [42] \\
\hline Wister rats & $\begin{array}{c}\text { NMN (i.p. } \\
100 \mathrm{mg} / \mathrm{kg} / \text { day) every } \\
\text { other day for } 28 \text { days. }\end{array}$ & $\begin{array}{l}\text { Hippocampal and Prefrontal } \\
\text { cortex tissue were examined; } \\
\text { the \% of increased NAD }{ }^{+} \text {level } \\
\text { was unspecified. }\end{array}$ & $\begin{array}{l}\text { Alleviate aging-induced } \\
\text { memory impairment; } \\
\text { improved mitochondrial } \\
\text { function and reduced } \\
\text { apoptosis in brain tissues. }\end{array}$ & Hosseini, et al. [43] \\
\hline
\end{tabular}

i.p, intraperitoneal; s.c, subcutaneous; Arc, arcuate nucleus; VMH, ventromedial hypothalamus; DMH, dorsomedial hypothalamus; LH, lateral hypothalamus. 
Besides the brain, experimental evidence supports the use of short-term administration of NMN for therapeutic effects on metabolic diseases, cardiovascular complications, and mitochondrial dysfunctions [27]. For example, NMN improves impairments in glucosestimulated insulin secretion in both genetic mouse models and aged wild-type mice [44]. NMN supplementation reduced adiposity in mice, and it had stronger effects on liver fat catabolism and synthesis even in comparison to exercise [45]. The NMN-mediated increase of $\mathrm{NAD}^{+}$levels has been shown to protect the heart from ischemia/reperfusion injury, sustains the neural stem/progenitor cell population, reestablishes skeletal muscle mitochondrial function and arterial function in aged mice, and facilitates mitochondrial function $[46,47]$. These results indicate that NMN can be quickly absorbed, efficiently transported in blood circulation, and taken up and converted to $\mathrm{NAD}^{+}$in different tissues. Enhancing $\mathrm{NAD}^{+}$biosynthesis with NMN may be an efficient therapeutic intervention against many disease conditions.

As a result of the potential high efficacy and benefits of NMN administration in various mouse models of human disease, several clinical trials administering NMN have been conducted recently [27]. Reports indicate that a single oral administration of NMN up to $500 \mathrm{mg}$ was safe and effectively metabolized in healthy subjects without causing severe adverse events [48,49]. More interestingly, a 10 week, randomized, placebo-controlled, double-blind trial to evaluate the effect of NMN supplementation in postmenopausal women with prediabetes has shown NMN increases muscle insulin sensitivity and insulin signaling in prediabetic women [50].

\section{Conclusions}

We report that supplemented NMN can increase $\mathrm{NAD}^{+}$in the mouse brain. Despite the tremendous research efforts aimed at exploiting the therapeutic potential of NMN to treat metabolic and aging-related diseases using dietary supplements, further research is suggested with regard to the prospects of developing drugs based on NMN [12]. In addition, human clinical trials are needed to explore the functional benefits of an increase in $\mathrm{NAD}^{+}$.

Author Contributions: C.R., Y.Z. and R.J.B. contributed to the conceptualization, methodology, investigation, data curation, visualization, supervision, writing, and editing. T.L., D.H.W. and P.S.S. contributed to data curation, investigation, and editing. All authors have read and agreed to the published version of the manuscript.

Funding: Support for this work was provided by CalerieHealth, LLC and the University of Memphis.

Institutional Review Board Statement: This study was conducted according to the guideline and approval of the institutional animal care and use committee (IACUC) from the University of Memphis (IACUC permit \#0872; 06/30/2021).

Informed Consent Statement: Not applicable.

Data Availability Statement: Data supporting the reported results were generated during the study and are not publicly available. Summary of the results related to this study can be accommodated on request from the corresponding author.

Acknowledgments: We thank the vivarium staff from the University of Memphis for their effort in animal care.

Conflicts of Interest: R.J.B. has served as a consultant to CalerieHealth, LLC. No other competing interests are declared.

\section{References}

1. Verdin, E. NAD+ in aging, metabolism, and neurodegeneration. Science 2015, 350, 1208-1213. [CrossRef]

2. Goodman, R.P.; Markhard, A.L.; Shah, H.; Sharma, R.; Skinner, O.S.; Clish, C.B.; Deik, A.; Patgiri, A.; Hsu, Y.-H.H.; Masia, R. Hepatic NADH reductive stress underlies common variation in metabolic traits. Nature 2020, 583, 122-126. [CrossRef]

3. Covarrubias, A.J.; Perrone, R.; Grozio, A.; Verdin, E. NAD+ metabolism and its roles in cellular processes during ageing. Nat. Rev. Mol. Cell Biol. 2021, 22, 119-141. [CrossRef] [PubMed] 
4. $\quad$ Fang, E.F.; Lautrup, S.; Hou, Y.; Demarest, T.G.; Croteau, D.L.; Mattson, M.P.; Bohr, V.A. NAD+ in aging: Molecular mechanisms and translational implications. Trends Mol. Med. 2017, 23, 899-916. [CrossRef] [PubMed]

5. Lee, C.F.; Caudal, A.; Abell, L.; Gowda, G.N.; Tian, R. Targeting NAD+ metabolism as interventions for mitochondrial disease Sci. Rep. 2019, 9, 1-10. [CrossRef] [PubMed]

6. Yoshino, J.; Baur, J.A.; Imai, S.-I. NAD+ intermediates: The biology and therapeutic potential of NMN and NR. Cell Metab. 2018, 27, 513-528. [CrossRef] [PubMed]

7. Shade, C. The Science Behind NMN-A Stable, Reliable NAD+ Activator and Anti-Aging Molecule. Integr. Med. A Clin. J. 2020, 19,12 .

8. Wang, G.; Han, T.; Nijhawan, D.; Theodoropoulos, P.; Naidoo, J.; Yadavalli, S.; Mirzaei, H.; Pieper, A.A.; Ready, J.M.; McKnight, S.L. P7C3 neuroprotective chemicals function by activating the rate-limiting enzyme in NAD salvage. Cell 2014, 158, 1324-1334. [CrossRef]

9. Camacho-Pereira, J.; Tarragó, M.G.; Chini, C.C.; Nin, V.; Escande, C.; Warner, G.M.; Puranik, A.S.; Schoon, R.A.; Reid, J.M.; Galina, A. CD38 dictates age-related NAD decline and mitochondrial dysfunction through an SIRT3-dependent mechanism. Cell Metab. 2016, 23, 1127-1139. [CrossRef]

10. Gomes, A.P.; Price, N.L.; Ling, A.J.; Moslehi, J.J.; Montgomery, M.K.; Rajman, L.; White, J.P.; Teodoro, J.S.; Wrann, C.D.; Hubbard, B.P. Declining NAD+ induces a pseudohypoxic state disrupting nuclear-mitochondrial communication during aging. Cell 2013, 155, 1624-1638. [CrossRef]

11. Yoshino, J.; Mills, K.F.; Yoon, M.J.; Imai, S.-I. Nicotinamide mononucleotide, a key NAD+ intermediate, treats the pathophysiology of diet-and age-induced diabetes in mice. Cell Metab. 2011, 14, 528-536. [CrossRef] [PubMed]

12. Poddar, S.K.; Sifat, A.E.; Haque, S.; Nahid, N.A.; Chowdhury, S.; Mehedi, I. Nicotinamide mononucleotide: Exploration of diverse therapeutic applications of a potential molecule. Biomolecules 2019, 9, 34. [CrossRef] [PubMed]

13. Yoon, M.J.; Yoshida, M.; Johnson, S.; Takikawa, A.; Usui, I.; Tobe, K.; Nakagawa, T.; Yoshino, J.; Imai, S.-I. SIRT1-mediated eNAMPT secretion from adipose tissue regulates hypothalamic NAD+ and function in mice. Cell Metab. 2015, 21, 706-717. [CrossRef]

14. Yao, Z.; Yang, W.; Gao, Z.; Jia, P. Nicotinamide mononucleotide inhibits JNK activation to reverse Alzheimer disease. Neurosci. Lett. 2017, 647, 133-140. [CrossRef] [PubMed]

15. Mills, K.F.; Yoshida, S.; Stein, L.R.; Grozio, A.; Kubota, S.; Sasaki, Y.; Redpath, P.; Migaud, M.E.; Apte, R.S.; Uchida, K. Long-term administration of nicotinamide mononucleotide mitigates age-associated physiological decline in mice. Cell Metab. 2016, 24, 795-806. [CrossRef] [PubMed]

16. Peek, C.B.; Affinati, A.H.; Ramsey, K.M.; Kuo, H.-Y.; Yu, W.; Sena, L.A.; Ilkayeva, O.; Marcheva, B.; Kobayashi, Y.; Omura, C. Circadian clock NAD+ cycle drives mitochondrial oxidative metabolism in mice. Science 2013, 342, 1243417. [CrossRef]

17. Stromsdorfer, K.L.; Yamaguchi, S.; Yoon, M.J.; Moseley, A.C.; Franczyk, M.P.; Kelly, S.C.; Qi, N.; Imai, S.-I.; Yoshino, J. NAMPTmediated NAD+ biosynthesis in adipocytes regulates adipose tissue function and multi-organ insulin sensitivity in mice. Cell Rep. 2016, 16, 1851-1860. [CrossRef]

18. Yamamoto, T.; Byun, J.; Zhai, P.; Ikeda, Y.; Oka, S.; Sadoshima, J. Nicotinamide mononucleotide, an intermediate of NAD+ synthesis, protects the heart from ischemia and reperfusion. PLoS ONE 2014, 9, e98972. [CrossRef]

19. Martin, A.S.; Abraham, D.M.; Hershberger, K.A.; Bhatt, D.P.; Mao, L.; Cui, H.; Liu, J.; Liu, X.; Muehlbauer, M.J.; Grimsrud, P.A. Nicotinamide mononucleotide requires SIRT3 to improve cardiac function and bioenergetics in a Friedreich's ataxia cardiomyopathy model. JCI Insight 2017, 2, e93885. [CrossRef]

20. Guan, Y.; Wang, S.-R.; Huang, X.-Z.; Xie, Q.-H.; Xu, Y.-Y.; Shang, D.; Hao, C.-M. Nicotinamide mononucleotide, an NAD+ precursor, rescues age-associated susceptibility to AKI in a sirtuin 1-dependent manner. J. Am. Soc. Nephrol. 2017, 28, $2337-2352$. [CrossRef]

21. Lin, J.B.; Kubota, S.; Ban, N.; Yoshida, M.; Santeford, A.; Sene, A.; Nakamura, R.; Zapata, N.; Kubota, M.; Tsubota, K. NAMPTmediated NAD+ biosynthesis is essential for vision in mice. Cell Rep. 2016, 17, 69-85. [CrossRef] [PubMed]

22. De Picciotto, N.E.; Gano, L.B.; Johnson, L.C.; Martens, C.R.; Sindler, A.L.; Mills, K.F.; Imai, S.I.; Seals, D.R. Nicotinamide mononucleotide supplementation reverses vascular dysfunction and oxidative stress with aging in mice. Aging Cell 2016, 15, 522-530. [CrossRef] [PubMed]

23. Stein, L.R.; Imai, S.i. Specific ablation of Nampt in adult neural stem cells recapitulates their functional defects during aging. EMBO J. 2014, 33, 1321-1340. [CrossRef] [PubMed]

24. Yoshino, J.; Imai, S.-I. Accurate measurement of nicotinamide adenine dinucleotide (NAD+) with high-performance liquid chromatography. Sirtuins 2013, 1077, 203-215.

25. Glaser, J.A.; Foerst, D.L.; McKee, G.D.; Quave, S.A.; Budde, W.L. Trace analyses for wastewaters. Environ. Sci. Technol. 1981, 15, 1426-1435. [CrossRef]

26. Harris, D.C. Quantitative Chemical Analysis; Macmillan: New York, NY, USA, 2010.

27. Hong, W.; Mo, F.; Zhang, Z.; Huang, M.; Wei, X. Nicotinamide mononucleotide: A promising molecule for therapy of diverse diseases by targeting NAD+ metabolism. Front. Cell Dev. Biol. 2020, 8, 246. [CrossRef]

28. Cantó, C.; Menzies, K.J.; Auwerx, J. NAD+ metabolism and the control of energy homeostasis: A balancing act between mitochondria and the nucleus. Cell Metab. 2015, 22, 31-53. [CrossRef]

29. Imai, S.-I.; Guarente, L. NAD+ and sirtuins in aging and disease. Trends Cell Biol. 2014, 24, 464-471. [CrossRef] 
30. Ramsey, K.M.; Yoshino, J.; Brace, C.S.; Abrassart, D.; Kobayashi, Y.; Marcheva, B.; Hong, H.-K.; Chong, J.L.; Buhr, E.D.; Lee, C. Circadian clock feedback cycle through NAMPT-mediated NAD+ biosynthesis. Science 2009, 324, 651-654. [CrossRef]

31. Imai, S.-I. "Clocks" in the NAD World: NAD as a metabolic oscillator for the regulation of metabolism and aging. Biochim. Biophys. Acta (BBA)-Proteins Proteom. 2010, 1804, 1584-1590. [CrossRef]

32. Liu, L.-Y.; Wang, F.; Zhang, X.-Y.; Huang, P.; Lu, Y.-B.; Wei, E.-Q.; Zhang, W.-P. Nicotinamide phosphoribosyltransferase may be involved in age-related brain diseases. PLOS ONE 2012, 7, e44933. [CrossRef] [PubMed]

33. Schöndorf, D.C.; Ivanyuk, D.; Baden, P.; Sanchez-Martinez, A.; De Cicco, S.; Yu, C.; Giunta, I.; Schwarz, L.K.; Di Napoli, G.; Panagiotakopoulou, V. The NAD+ precursor nicotinamide riboside rescues mitochondrial defects and neuronal loss in iPSC and fly models of Parkinson's disease. Cell Rep. 2018, 23, 2976-2988. [CrossRef]

34. Stein, L.R.; Wozniak, D.F.; Dearborn, J.T.; Kubota, S.; Apte, R.S.; Izumi, Y.; Zorumski, C.F.; Imai, S.-I. Expression of Nampt in hippocampal and cortical excitatory neurons is critical for cognitive function. J. Neurosci. 2014, 34, 5800-5815. [CrossRef] [PubMed]

35. Garten, A.; Schuster, S.; Penke, M.; Gorski, T.; De Giorgis, T.; Kiess, W. Physiological and pathophysiological roles of NAMPT and NAD metabolism. Nat. Rev. Endocrinol. 2015, 11, 535-546. [CrossRef]

36. Liu, D.; Pitta, M.; Jiang, H.; Lee, J.-H.; Zhang, G.; Chen, X.; Kawamoto, E.M.; Mattson, M.P. Nicotinamide forestalls pathology and cognitive decline in Alzheimer mice: Evidence for improved neuronal bioenergetics and autophagy procession. Neurobiol. Aging 2013, 34, 1564-1580. [CrossRef]

37. Lu, L.; Tang, L.; Wei, W.; Hong, Y.; Chen, H.; Ying, W.; Chen, S. Nicotinamide mononucleotide improves energy activity and survival rate in an in vitro model of Parkinson's disease. Exp. Ther. Med. 2014, 8, 943-950. [CrossRef]

38. Long, A.N.; Owens, K.; Schlappal, A.E.; Kristian, T.; Fishman, P.S.; Schuh, R.A. Effect of nicotinamide mononucleotide on brain mitochondrial respiratory deficits in an Alzheimer's disease-relevant murine model. BMC Neurol. 2015, 15, 1-14. [CrossRef]

39. Park, J.H.; Long, A.; Owens, K.; Kristian, T. Nicotinamide mononucleotide inhibits post-ischemic NAD+ degradation and dramatically ameliorates brain damage following global cerebral ischemia. Neurobiol. Dis. 2016, 95, 102-110. [CrossRef] [PubMed]

40. Wang, X.; Hu, X.; Yang, Y.; Takata, T.; Sakurai, T. Nicotinamide mononucleotide protects against $\beta$-amyloid oligomer-induced cognitive impairment and neuronal death. Brain Res. 2016, 1643, 1-9. [CrossRef]

41. Johnson, S.; Wozniak, D.F.; Imai, S. CA1 Nampt knockdown recapitulates hippocampal cognitive phenotypes in old mice which nicotinamide mononucleotide improves. npj Aging Mech. Dis. 2018, 4, 1-12. [CrossRef]

42. Klimova, N.; Long, A.; Kristian, T. Nicotinamide mononucleotide alters mitochondrial dynamics by SIRT3-dependent mechanism in male mice. J. Neurosci. Res. 2019, 97, 975-990. [CrossRef]

43. Hosseini, L.; Farokhi-Sisakht, F.; Badalzadeh, R.; Khabbaz, A.; Mahmoudi, J.; Sadigh-Eteghad, S. Nicotinamide mononucleotide and melatonin alleviate aging-induced cognitive impairment via modulation of mitochondrial function and apoptosis in the prefrontal cortex and hippocampus. Neuroscience 2019, 423, 29-37. [CrossRef] [PubMed]

44. Spinnler, R.; Gorski, T.; Stolz, K.; Schuster, S.; Garten, A.; Beck-Sickinger, A.G.; Engelse, M.A.; de Koning, E.J.; Körner, A.; Kiess, W. The adipocytokine Nampt and its product NMN have no effect on beta-cell survival but potentiate glucose stimulated insulin secretion. PLoS ONE 2013, 8, e54106. [CrossRef] [PubMed]

45. Uddin, G.M.; Youngson, N.A.; Doyle, B.M.; Sinclair, D.A.; Morris, M.J. Nicotinamide mononucleotide (NMN) supplementation ameliorates the impact of maternal obesity in mice: Comparison with exercise. Sci. Rep. 2017, 7, 1-11. [CrossRef]

46. Hosseini, L.; Vafaee, M.S.; Badalzadeh, R. Melatonin and nicotinamide mononucleotide attenuate myocardial ischemia/reperfusion injury via modulation of mitochondrial function and hemodynamic parameters in aged rats. J. Cardiovasc. Pharmacol. Ther. 2020, 25, 240-250. [CrossRef]

47. Jafari-Azad, A.; Hosseini, L.; Rajabi, M.; Høilund-Carlsen, P.F.; Vafaee, M.S.; Feyzizadeh, S.; Badalzadeh, R. Nicotinamide mononucleotide and melatonin counteract myocardial ischemia-reperfusion injury by activating SIRT3/FOXO1 and reducing apoptosis in aged male rats. Mol. Biol. Rep. 2021, 48, 3089-3096. [CrossRef]

48. Tsubota, K. The first human clinical study for NMN has started in Japan. npj Aging Mech. Dis. 2016, 2, 1. [CrossRef]

49. Irie, J.; Inagaki, E.; Fujita, M.; Nakaya, H.; Mitsuishi, M.; Yamaguchi, S.; Yamashita, K.; Shigaki, S.; Ono, T.; Yukioka, H. Effect of oral administration of nicotinamide mononucleotide on clinical parameters and nicotinamide metabolite levels in healthy Japanese men. Endocr. J. 2020, 67, 153-160. [CrossRef]

50. Yoshino, M.; Yoshino, J.; Kayser, B.D.; Patti, G.J.; Franczyk, M.P.; Mills, K.F.; Sindelar, M.; Pietka, T.; Patterson, B.W.; Imai, S.-I. Nicotinamide mononucleotide increases muscle insulin sensitivity in prediabetic women. Science 2021, 372, 1224-1229. [CrossRef] 